\title{
A COMPARATIVE STUDY ON THE ENGLISH TEACHING SKILLS BETWEEN THE CERTIFIED AND NON-CERTIFIED ENGLISH TEACHERS IN BANTAENG REGENCY
}

\author{
Dzur Rif'ah Mahmudah \\ English Education Department, Faculty of Teacher Training and Education \\ Muhammadiyah University of Makassar
}

\begin{abstract}
This study compares the English teaching skills between certified and non-certified English teachers and the endeavors are dominantly done by both in developing the English teaching skills. Causal comparative design was used to investigate the candidate of Junior and Senior High Schools certified and non-certified English teachers in Bantaeng Regency based on their scores from two standadrdized instruments. Study result indicated that there was no significant different English teaching skills between certified and non-certified English teachers. In addition, the dominant endeavors done by the certified and non-certified English teachers was revealed that most of certified and non-certified English teachers were active in cognitive stage rather than in practice and evaluation stage. Based on the findings, the researcher deduced that both certified and non-certified English teachers in Bantaeng Regency have no significant difference in the English teaching skills because of both English teachers have similar endeavors in developing their skills.
\end{abstract}

Keywords: English teaching skills, certified English teachers, non-certified English teachers, endeavors, developing skills.

Teaching skills is a form of tutoring action. It is the accumulation of knowledge which has been obtaining by the teachers during they go through the education, both formal (university) and informal (teachers training) education. In general, there are some skills in teaching such as the skills to ask; skills to stimulate, reward, and punishment; skills to present the material, skills to manage classroom, etc (Risal, 2011).

As such, the application of 2013 curriculum requires teachers to have some skills in teaching to achieve the objectives in the 2013 curriculum. The skills that are expected to have such as the skills to analyze the relationship between the Graduation Competency Standards (SKL), Core Competencies (KI), Basic Competency (KD), teachers book and learners book; skills to write lesson plan (RPP) by referring to the curriculum in 2013; skills to use scientific approach in teaching correctly; skills to apply the learning model of Problem Based Learning, Project Based Learning, and Discovery Learning; skills to implement authentic 
assessment properly, and oral and written communication skills with a coherent, correct, and polite (Kementrian Pendidikan dan Kebudayaan, 2013).

Based on the Act No. 14 of 2005 and Government Regulation No. 74 of 2008 mandates that teachers are required to have a minimum qualification of a bachelor (S-1) or Diploma (D-IV), master competencies (pedagogical, professional, social and personality), a certified educator, physical and spiritual health, as well as having the ability to achieve national education goals (Rustad, et al., 2012).

Teacher certification is a qualification required for becoming teachers whose intention to attain the goal of National Education Standard. According to the Act No. 14 of 2005 on Teachers and Lecturers Article 1, Paragraph 10, mentioned that competence is a set of knowledge, skills, and behaviors that must be possessed, internalized and controlled by teachers or lecturers in implementing the task of professionalism. While, article 10 paragraph 1 stated that educators competence as agents of learning in elementary, secondary, and early childhood education include: (a) pedagogic competence, (b) personality competence, (c) professional competence, and (d) social competence (Undang-undang Guru dan Dosen, 2009).

However, with regard to the improvement of teachers' quality, the goals of the teachers' certification program still cannot be achieved maximally in general. This is caused by a principle problem of the teachers is still on in terms of their teaching skills and behaviors. In terms of teaching, most teachers are not nimble and creative as well as both very low in knowledge acquisition and learning methods. Thus, when teachers teach, they tend to be conservative and oldfashioned (Muhajir, 2013).

In Bantaeng, the fact from the result of Teachers Competence Test of 2013 (UKG 2013) showed that most of the English teachers (80\%) in Bantaeng Regency have not been able to reach the competence in maximum level yet. They still have to join the Base Training and Follow-up Training. They are demanded to have more pedagogical competence especially skills, creative, and innovative in teaching English (Syafei, 2014). 


\section{REVIEW OF LITERATURE}

The study of Soepriyatna (2013) reported the competence required by high school teachers of English in Indonesia (HSTEI) are three competences: English language competence, content knowledge, and teaching skills Soepriyatna (2013) added that the teachers should have the ability to transfer the knowledge in effective teaching techniques adapted to their own classroom contexts. Ahmad \& Setyaningsih (2012) investigated the teachers of Junior, Senior, and Vocational High School who joined the Teacher Professionalism Education and Training Program (PLPG). Statistically, it showed that the teachers professional in pedagogic side include their teaching skills belonged to medium level $(69.7 \%)$.

\section{Teaching Skills}

Skill is an acquired ability to perform an activity well, usually one that is made up of a number of co-ordinated processes and actions (Richard \& Schmidt, 2010). While, DeQueliy dan Gazali (quoted by Slameto, 2010) define teaching is invest knowledge to someone briefly and appropriately. Howard (quoted by Slameto, 2010) argues that teaching is an activity to help and guide someone to get, change, and develop his or her skills, attitudes, ideals, appreciations, and knowledge.

Based on the definition above, the researcher conclude that teacher teaching skills is the ability of teachers to perform teaching activity effectively in helping the learners to get, change, and develop their skills, attitudes, ideals, appreciations, and knowledge.

Generally, teaching process comprises three basic steps: planning the instruction, delivering the instruction planned, and assessing the learners' outcomes (Grant, Hindman, Stronge, 2013). Notice that, to carry out the teaching process, the three steps should be aligned with one another. The planned instruction should be logically related to the actual instruction and the assessments should relate to the plans and instructions.

The essential teaching skills involved in contributing to successful classroom practice can be identified and described as follows (Kyaricou, 2007):

a. Lesson Planning Skills 
Kyriacou, (2007) said that the skills of lesson planning involved in selecting the educational aims and learning outcomes intended for a lesson and how best to achieve these.

Based on the description above, the researcher decides that lesson planning skills consist of four indicators, those are: a) objectives, b) course content and method, c) instructional activities, d) assessment.

b. Lesson Presentation Skills

Lesson presentation refers to the learning experiences the teacher set up to achieve the intended learning outcomes by learners. As a result of the many different types of teaching methods that have been developed, there is now a staggering range of learning actpivities available that can be deployed to good effect. These include, by way of example, exposition, practicals, worksheets, ICT, role play, and small group discussion. Moreover, teachers are actively encourage and expected to make use of a variety of teaching methods in their programme of lessons (Kyriacou, 2007).

Based on the elaboration above, the researcher concludes that the indicators of lesson presentation skills are: a) set induction, b) explaining, c) questioning, d) conduct a variation activities, e) reinforcing, f) closing.

c. Assessing the Learners' Outcome Skills

All teachers have to be able to assess the learners' outcomes refer to the goal. There are two ways that the teachers can be used: illuminative-observative and structural-objective. Illuminative-observative is the way to assess the learners' outcomes by observing the learners changes and outcomes continuously, either during or after the lesson is thorough. Structural-objective is related to the way of giving score, grade, and value of the learners' outcomes (Sa'ud, 2009).

Based on the elaboration above, the researcher concludes that the indicators of assessing the learners' skills are illuminative-observative include diagnostic, formative, and summative purposes of assessment; and structural-objectives.

\section{The Development of Teaching Skills}

The teachers develop their teaching skills by looking at the efforts of experienced teachers to monitor and develop their own skills or to assist with developing those of colleagues. Studies reporting the efforts of experienced 
teachers to develop their teaching skills well illustrate that all teachers, not just beginning teachers, are continually in such development. Indeed, this is the sense that teaching skills continually need development to meet new demands that makes teaching such a challenging profession (Kyriacou, 2007).

Perrott (quoted by Kyriacou, 2007) analyzes on how teaching skills are acquired and developed. It focuses on three stages, cognitive, practice, and feedback (evaluation). She sees this three stage process as a cycle, in which the third stage evaluation into the first stage as part of an on-going development of the skill.

\section{Professional Teacher}

Richey (quoted by Satori, 2012) describes several characteristics of professional teacher below:

a. The teachers will work solely to provide services for the benefit of humanity rather than personal effort.

b. The teachers are legally required to meet the various requirements to obtain a license to teach as well as strict requirements to become a member of teachers organization.

c. The teachers are required to have a high understanding and skills in terms of teaching materials, methods, learners, and educational foundation.

d. The teachers in professional organizations have professional publications that serve the teachers to follow the changes that occur.

e. The teachers have always endeavored to follow the courses, workshop seminars, conventions and are widely involved in various activities in service.

f. The teachers are recognized fully as a life career.

g. The teachers have the values and ethics that serve both nationally and locally.

The description of the professional teachers' characteristics above produce a conclusion that the professional teachers should have two criterias: 1) a high understanding and skills in terms of teaching materials, methods, learners, and educational foundation; 2) endeavor to follow the courses, workshop seminars, conventions and are widely involved in various activities in service continuously.

Certification is an effort to improve teacher quality coupled with an increase in the prosperity of teachers so as to improve the quality of learning and the 
quality of education in Indonesia on an ongoing basis. Form of an increase in teachers' prosperity in the form of one-time allowance base salary for teachers who have certification. The allowance applies to both teachers with the status of civil servants and non-civil-status teacher (The Act No 14 of 2005 on Teachers and Lecturers in Undang-undang Guru dan Dosen, 2009).

Based on the Act No. 14 of 2005 and Government Regulation No. 74 of 2008 mandates that teachers are required to have a minimum qualification of a bachelor (S-1) or Diploma (D-IV), master competencies (pedagogical, professional, social and personality), a certified educator, physical and spiritual health, as well as having the ability to achieve national education goals (Rustad, et al., 2012).

Teacher certification program is done selectively and gradual. Selectively means certification test is done through a series of selection. It begin from administration selection, writing test, performance test, until portfolio assessment. Gradual means that certification test will be done gradually every year appropriate with the capability of certification program organizer or government. Remembering the total of teacher is very much, so that impossible to cover them at once.

\section{METHOD}

\section{Research Design}

A causal comparative design was suitable to be employed. The researcher attempted to determine the cause or reason for existing differences in the behavior or status of groups of individuals. The basic causal-comparative design involved selecting two groups differing on some independent variable and comparing them on some dependent variable (Gay, Mills, \& Airasian, 2006).

\section{Variable}

There was one categorical independent variable which differentiating two groups, certified and non-certified English teachers and one quantitative dependent variable (teaching skills).

1. Certified English teachers were whoever had joined the Teacher Professionalism Education and Training Program (PLPG) and passed the final 
examinations. Whereas, non-certified English teachers were whoever had not joined the PLPG or whoever had joined the PLPG but did not pass the final examinations.

2. English teaching skills was a set of teachers' activities which foster learner to learn. Teaching skills are involved in contributing to successful classroom practice can be identified based on three teaching process, those are: lesson planning skills, lesson presentation skills, and assessing learners' outcomes skills.

\section{POPULATION AND SAMPLE}

The population of the study was the certified and non-certified English teachers in Bantaeng Regency. They taught in Junior and Senior High Schools. The sample was determined by referring the table of determining sample from certain population. This table was developed from Isaac and Michael for the error degree 5\%. The sample was 62 English teachers which consisted of 34 certified English teachers and 28 non-certified English teachers.

\section{INSTRUMENT}

This study typically used one basic instrument that was questionnaire which consisted of five parts: a cover letter, closed-ended questions asking participants about their background, rating scales addressing teaching skills performance, closed-ended questions addressing participants' attitudes about their endeavor in developing the teaching skills, and closing instructions thanking the respondent for taking part in the study.

\section{PROCEDURE OF COLLECTING DATA}

In collecting the data, the researcher went through some steps, as follows:

1. Piloted the Questionnaire

Rating scale was used to measure the teaching skills. This rating scale was constructed based on the theory or opinion which was proposed by Kyriacou (2007). It was used to measure the teaching skills based on three teaching process, those are: lesson planning skills, lesson presentation skills, and assessing the learners' outcomes skills. 
Validity test of the rating scale use correlation technique called product moment from pearson. It analyzed by using the operation of Microsoft Excel 2010 (see appendix 3). From 40 items found $\mathrm{r}$ count was $-0.69-0.77$, while $\mathrm{r}$ table $=$ 0.25. So that there were 24 items of rating scale was valid. The reability coefficient of rating scale was tested by Cronbach's Alpha adalah rxy $=0,988$ (see appendix 4). It means the rating scale was reliable and it can be used to gather data.

2. Distributing the Questionnaire

In this step, the researcher meets the participants in the schools and asks to fill the questionnaire which has been piloted before.

3. Filling in the Questionnaire

The researcher described how to fill the questionnaire at that time and then take the completed questionnaire in the next day.

\section{DATA ANALYSIS}

The data was analyzed in some steps below:

\section{Rating Scales}

The rating scale scoring was carried out in the different place to be processed. This questionnaire consisted of two attributes, favorable (F) and unfavorable (UF). One of the response forms that are used is four-choice form. In this study, the researcher use form of 4 = always, $3=$ almost always, $2=$ hardly ever, and $1=$ never.

In scoring, the positif respons toward favorable items scored from $1-4$ for favorable items and from $4-1$ for unfavorable items.

The data were analyzed by using inferential statistics, independent sample $t$ test. It used to determine if there is significant difference among the means of two groups (Gay, Mills, \& Airasian, 2006). The technique of the data analysis will be analyzed by using computer program was named SPSS 18.0, for windows.

2. Closed-ended Questions

In this part, the researcher provided three questions followed by limited number of response options. The all options were scored as one (1). 


\section{FINDINGS}

\section{The Teaching Skills of Certified and Non-Certified English Teachers}

The result of the study through the distribution score of certified and noncertified English teachers indicated that most of certified English teachers who teach in Junior and Senior High School level were categorized as high level teaching skills. There were 4 certified English teachers or $11.76 \%$ in very high level teaching skills, 27 certified English teachers or $79.41 \%$ in high level, and 3 or $4.64 \%$ in low level. Whereas, for the non-certified English teachers in table 4.1 showed that all of them were in High level (28 or 100\% teachers). Moreover, based on statistics test in probability value (significant 2-tailed). The probability is higher than alpha $(0.151>0.05)$. It means that $\mathrm{Ha}$ is rejected and $\mathrm{H} 0$ is accepted. It means that the teaching skills of certified and non-certified English teachers were not significantly different.

\section{The Endeavors of the Certified and Non-Certified English Teachers in Developing the Teaching Based on Three Stages of Skill Development.}

The dominant endeavors done by both certified English teachers are cognitive stage. The certified English teachers who were very active and active in cognitive stage totally are 29 or $85.5 \%$, while in practice stage totally were 14 or $41.1 \%$ teachers, and there were 15 or $44.7 \%$ teachers who were active in evaluation stage. The same case wqs also appeared by the non-certified English teachers' endeavors. There were 17 or $54.4 \%$ non-certified English teachers were very active in cognitive stage; while in practice and evaluation stage, there were 3 or $10.71 \%$ non-certified English teachers were in active level.

Conversely, the certified English teachers who were inactive in cognitive stage were only 5 or $14.7 \%$, in practice stage were 20 or $58.8 \%$, and in evaluation stage were 19 or $55.9 \%$ teachers. Moreover, the result also indicated the noncertified English teachers who are inactive in cognitive stage were only 11 or $39.29 \%$ compare with both in practice and evaluation stage were 25 or $89.29 \%$ non-certified English teachers. 


\section{DISCUSSION}

The result of endeavors of both certified and non-certified English teachers in Bantaeng Regency showed that they have a similar endeavors in developing teaching skills. They are only dominantly active in cognitive stage. Sujanto (2009) said that the teacher who has been joined the certification program means that the teacher has passed the first step of being a professional teacher. Then, the next step of being a professional teacher is improving the professionalism. One of the way to improve the professionalism is improving self-development in terms of developing skills in teaching. Perrott (quoted by Kyriacou, 2007) identified three stages of skill development: cognitive, practice, and evaluation. She sees that the three stages is a cycle, in which the all stages is a part of an on-going development of the skill. It means that the professional teachers should have to be dominantly active in all three stages of skill development, not only in one stage as showed in the result of this research.

\section{CONCLUSION}

Based on the findings, it can be concluded that:

1. There was no significant difference in the English teaching skills between certified and non-certified English teachers in Bantaeng Regency. These findings can occured because of a possibility, which are the endeavors of both subject were generally similar based on the second research result.

2. The endeavors of both groups in developing teaching skills were actively in cognitive stage. There was no on-going process on three stages of skill development in the endeavors of both certified and non-certified English teachers in Bantaeng Regency. It means that the certified English teachers were still have low motivation in developing their skills especially in English teaching.

\section{BIBLIOGRAPHY}

Ahmad \& Setyaningsih, E. 2012. Teacher Professionalism: A Study on Teachers' Professional and Pedagogic Competence at Junior, Senior, and Vocational 
High Schools in Banyumas Regency, Central Java, Indonesia. Sosiohumanika, 5(1), 93-106.

Ali, N., et. al. 2013. Keterampilan Dasar Mengajar. Jogjakarta: Ar-Ruzz Media.

Alma, et al. 2009. Guru Profesional: Menguasai Metode dan Terampil Mengajar. Bandung: Alfabeta.

Azwar, S. 2001. Reliabilitas dan Validitas. Yogyakarta: Pustaka Pelajar.

Bailey, M. K. (2006). Language Teacher Supervision: A Case-Based Approach. Cambridge: Cambridge University Press.

Borich, G. D. 2006. Effective Teaching Methods: Research-Based Practice Sixth Edition. New Jersey: Pearson Merrill Prentice Hall

Buku Kerja. 2012. Panduan Penentuan Skoring Kriteria. (Online), (http://www.bukukerja.com/2012/10/panduan_penentuan_skoring_kriteria. html, accessed August, $13^{\text {th }}$ 2014)

Creswell, J. H. 2008. Educational Research: Planning, Conducting, and Evaluating Quantitative and Qualitative Research (3th Ed.). New Jersey: Pearson Education, Inc.

Crystal, D. (2003). English as A Global Language (2nd Ed.). Cambridge: Cambridge University Press.

Gay, L. R., Mills, G. E., \& Airasian, P. 2006. Educational Research: Competencies for Analysis and Application. New Jersey: Pearson Education, Inc.

Grant, W. L., Hindman, L. J., Stronge, J. H. 2013. Planning, Instruction, and Assessment: Effective Teaching Practices. New York: Routledge.

Jalal, F., et al. 2009. Teacher Certification in Indonesia: A Strategy for Teacher Quality Improvement. Jakarta: Departemen Pendidikan Nasional. 
Johnson, B. \& Christensen, L. 2004. Educational Research: Quantitative, Qualitative, and Mixed Approaches $2^{\text {nd }}$ ed. United States of America: Pearson Education, Inc.

Kelly, 2001. Planning Instruction. (Online), (http://712educators.about.com/od/teachingstrategies/a/planning_task.htm, accessed October, $27^{\text {th }} 2013$. 